\title{
THE INFLUENCE OF FSH, LH AND TESTOSTERONE ON THE SEXUAL BEHAVIOUR AND TESTICULAR FUNCTION OF THE BOAR
}

\author{
F. ELLENDORFF, E. ROTH AND D. SMIDT \\ Institut für Tierzucht und Haustiergenetik, Göttingen, Germany
}

(Received 19th September 1969)

Sexual maturity can be advanced in the sow by hormonal treatment (Schahidi, 1968; Majerciak, Smidt, Schahidi \& Harms, 1969) but has not been tried successfully in the boar.

Ten boars were investigated under the normal conditions of the experimental station (Roth, 1969). Table 1 shows the age and treatment schedule. The following substances were used: FSH(NIH-FSH-Pl), LH(NIH-LH-B6), and Testoviron (Testoviron - Depot, Schering AG Berlin). Biopsies were taken at the intervals shown in Table 1. Castration was performed on the 53rd day of the experiment.

The following aspects of sexual behaviour were studied: sexual excitement, indicated by aggressiveness towards other boars, frothing from the mouth, and interest in sows in oestrus, as shown by mounting and erection of the penis with and without protrusion from the prepuce. In order to evaluate gonadal function, biopsy material was used to investigate testicular development morphologically and histologically. The same material was used to collect data on spermatogenic processes. Electro-ejaculates were collected from the boars once a week in order to determine the earliest date by which spermatozoa can be obtained.

The results from observations of sexual behaviour are shown in Table 2. After 10 days, the youngest age group displayed obvious sexual excitement. Sows in oestrus were vigorously mounted and penis erection occurred in the prepuce. No protrusion was observed. On the 50th day, all symptoms of sexual behaviour were greatly reduced. Similar observations were made in the second age group. In the oldest age group, erection of the penis outside the prepuce took place after the first injection of hormones.

From this, it was concluded that hormonal treatment could advance the onset of sexual behaviour as compared with controls. After the end of treatment, the sexual activity in the two oldest groups continued but in the youngest group, it decreased.

Data are presented in Table 3 on the change in the diameter of the tubules, the number of tubules per $\mathrm{mm}^{2}$, and the percentage of tubular tissue present in the testis. There were no significant differences between the experimental groups and the controls, showing that the hormones injected did not have a 
stimulatory effect. Similarly, spermatogenesis in the tubules could not be enhanced by the hormone treatment. The stages of spermatogenesis (spermatogonia to mature spermatozoa) visible in the testes of hormone-treated animals were compared with those which had developed in the testes of the control animals. During the later phase of the treatment, the boars in the control group had reached the more advanced stages. This was shown by the results of electro-ejaculation. Spermatozoa were only obtained from two animals in the oldest age group treated with hormones.

The results show that the sexual behaviour of the immature boar can be stimulated by the hormone dosages used. Sexual maturity, as judged by tubular morphology and histology, cannot, however, be enhanced.

\section{TABLE 1}

TREATMENT SGHEDULE FOR THE ADMINISTRATION OF FSH, LH AND TESTOSTERONE TO BOARS OF DIFFERENT AGES

\begin{tabular}{|c|c|c|c|c|}
\hline Animal No. & Age group & $\begin{array}{l}\text { Age in days at } \\
\text { first treatment }\end{array}$ & Treatment & Day \\
\hline 1 to 4 & I & 72 & Treated animals: & \\
\hline 5 to 7 & II & 83 & FSH : $2.8 \mathrm{mg}$ & $1,3,5,7,9,11,13,15,17,19$ \\
\hline 8 to 10 & III & 105 & $\begin{array}{l}\text { Testosterone: } 400 \mathrm{mg} \\
\text { All animals: } \\
\text { Biopsy: right testis } \\
\text { left testis } \\
\text { Castration }\end{array}$ & $\begin{array}{l}1,9,(150 \mathrm{mg}), 15,(100 \mathrm{mg}) \\
1 \\
16 \\
53\end{array}$ \\
\hline
\end{tabular}

It is assumed that the biopsies damaged the germinative part of the testes. Investigations on the testes showed that lesions occurred in the testicular tissue and that, on healing, adhesions formed between the testes and the scrotum. However, in most of the boars, no pathological disturbances were detected which would exclude further sexual development.

It is probable that the hormone dosages were not large enough to hasten sexual maturity. Testosterone, and also possibly LH, by way of its action on interstitial tissue, probably caused the premature sexual behaviour. FsH did not stimulate spermatogenesis as it does in mature animals.

In order to explain the difference between the results of attempts to induce sexual development in the sow (Schahidi, 1968; Majerciak, Smidt, Schahidi \& Harms, 1969) and the boar, further investigations are needed. The hormonal combination used in this experiment with boars may be insufficient in absolute and/or relative amounts, or boars may have a different mechanism controlling sexual maturity.

FSH(NIH-FSH-P1) and LH(NIH-LH-B6) were kindly supplied by Dr Wilhelmi, Emroy University, with the aid of the National Institute of Health, Bethesda, Maryland, U.S.A. 


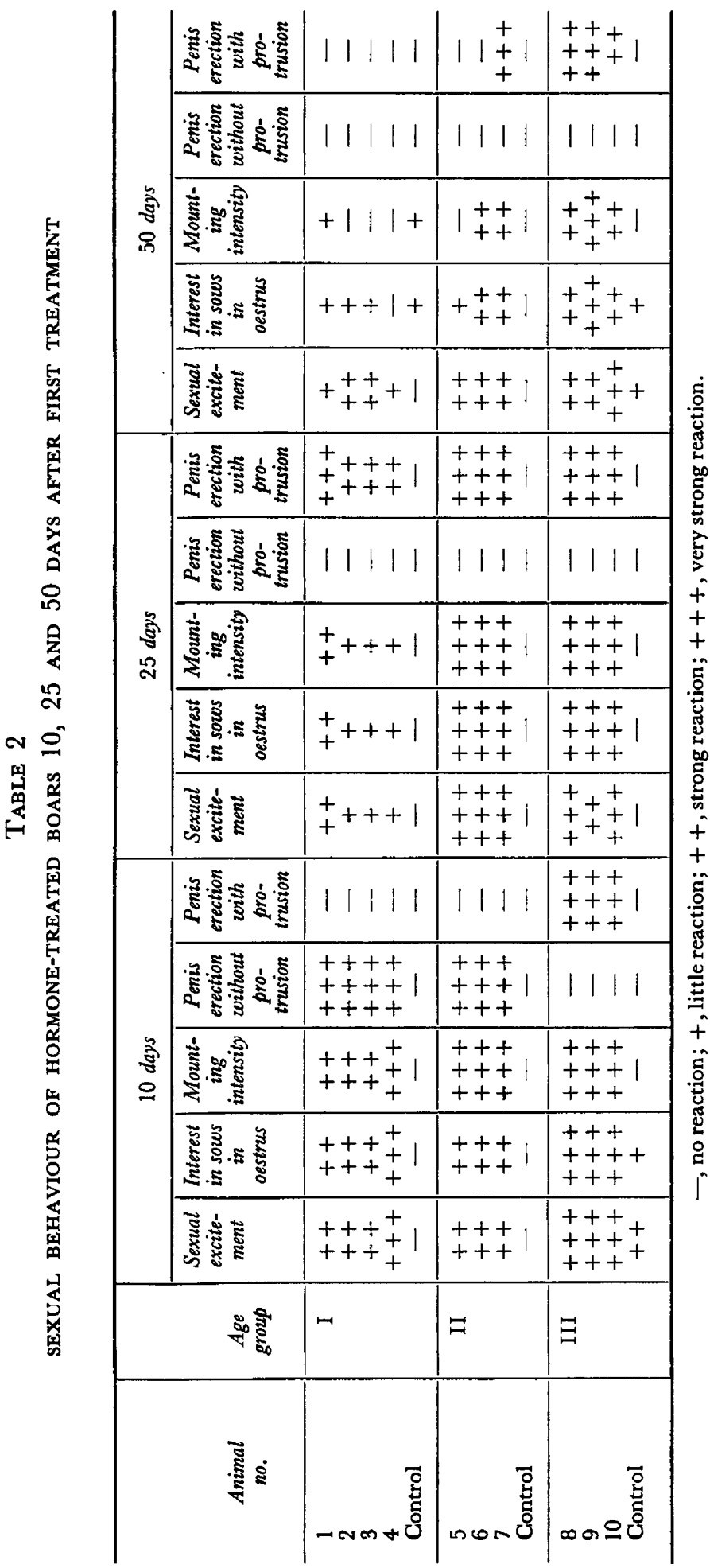




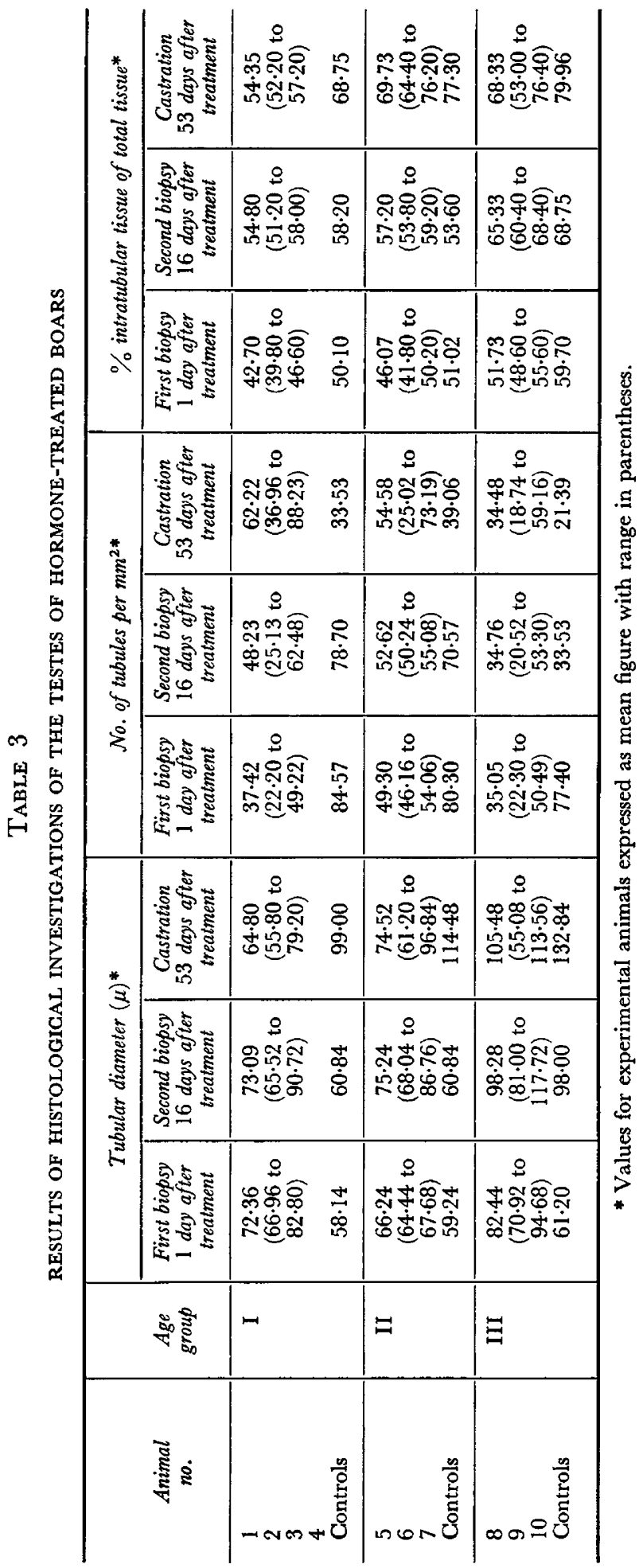




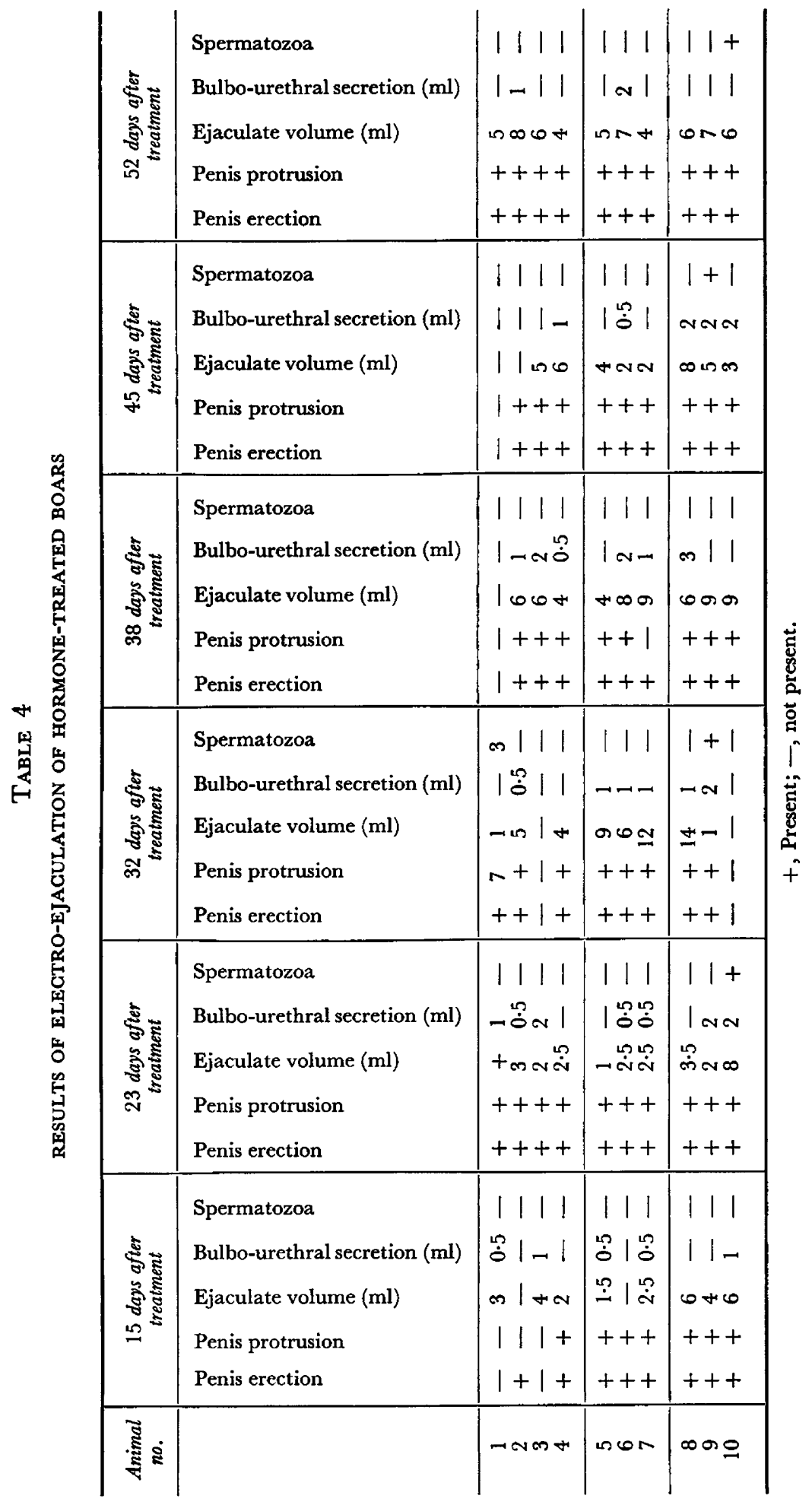




\section{REFERENCES}

Majerciak, P., Smidt, D., Schahidi, R. \& Harms, E. (1969) Untersuchungen zur Eigewinnung von infantilen weiblichen Schweinen. 1. Mitteilung. Z. Tierzücht. ZüchtBiol. (in press).

Rотн, E. (1969) Die geschlechtliche Entwicklung bei Eberm unter besonderer Berücksichtigung der Möglichkeit frühzeitiger Spermagewinnung. Dissertation, Göttingen.

ScHAнid, R. (1968) Untersuchungen zur Eigewinnung bei infantilen weiblichen Schweinen. Dissertation, Göttingen. 